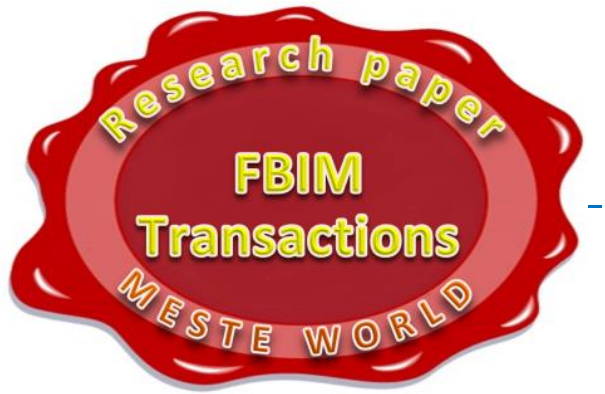

\title{
RESEARCH ON THE DEVELOPMENT PATH OF NINGBO TRANSPORTATION EQUIPMENT MANUFACTURING INDUSTRY IN 16 CEEC
}

\section{Bo Wang}

Ningbo University of Technology, Ningbo, Zhejiang, China

\author{
Danjuan Hu \\ Ningbo University of Technology, Ningbo, Zhejiang, China
}

CMESTE

JEL Category: L62, L91, 018

\begin{abstract}
Ningbo's transportation equipment manufacturing enterprises have reached the world's leading level in technology, but the CEEC, whose economic level surpasses our country, are lagging behind in terms of transportation infrastructure construction. With the promotion of the "One Belt and One Road" strategy, the well-developed transportation equipment manufacturing industry in Ningbo hopes to enter the vast market of CEE, and CEEC also urgently need to improve the status quo of domestic transportation infrastructure construction. In this context, based on the science and technology cooperation alliance between our university and universities in CEE, the external output of Ningbo's advanced transportation equipment manufacturing industry can be achieved by carrying out long-term cooperation forum activities, jointly applying for international science and technology cooperation projects and human resources exchange training cooperation and decision-making consultation service cooperation, etc. to improve China's position in the global industrial chain and value chain and promote the deep integration of economic cooperation among countries along the One Belt and One Road.
\end{abstract}

Keywords: transportation equipment manufacturing industry; CEE; S\&T cooperation alliance; output

\section{INTRODUCTION}

With the continuous deepening of China's "One Belt and One Road" strategy, the Ministry of

Address of the corresponding author:

Bo Wang

棒' bo305@hotmail.com
Science and Technology has advocated to actively promote the export a large number of advanced and applicable technologies and scientific and technological talents accumulated in China to the countries along the line. As a competitive industry in China, transportation equipment manufacturing has reached the world's leading level in technology. As countries along the "One Belt and One 
Road" initiative, the 16 countries in CEE are relatively backward in terms of infrastructure and have an urgent need for interconnection and infrastructure construction, which provides a good opportunity for China's transportation equipment manufacturing industry.

As a strategic fulcrum city for the country's CEE strategy, Ningbo City has a good foundation for cooperation with CEE. We intend to provide services to the development of the CEE cooperation partners and China's transportation equipment manufacturing industry in the 16 countries in CEE through the scientific and technological cooperation alliance, thereby outputting equipment manufacturing standards to meet the external expansion needs of Ningbo's advanced transportation equipment manufacturing industry and improve China's position in the global industrial chain and value chain and promote the deep integration of economic cooperation among countries along the One Belt and One Road.

\section{ANALYSIS OF THE STATUS QUO OF THE TRANSPORTATION INFRASTRUCTURE CONSTRUCTION IN 16 COUNTRIES IN CEE}

16 countries in CEE as countries along China's "One Belt and One Road" initiative, from the perspective of per capita income and per capita GDP (figure 1), half of the countries' economic level has surpassed China's, or even more than China's, but most countries are relatively backward in infrastructure construction, and transportation facilities such as railways, roads and ports are facing renewal problems. Calculate according to the total infrastructure investment accounted for about $5 \%$ of GDP, the demand for infrastructure in CEEC reached $\$ 68.03$ billion in 2015 , while the turnover of engineering contracting projects in CEEC was $\$ 1.18$ billion, only accounting for $1.73 \%$ of them (figure 2). It can be seen that China and the 16 countries in CEE have extensive space for cooperation and development in the construction of transportation infrastructure.

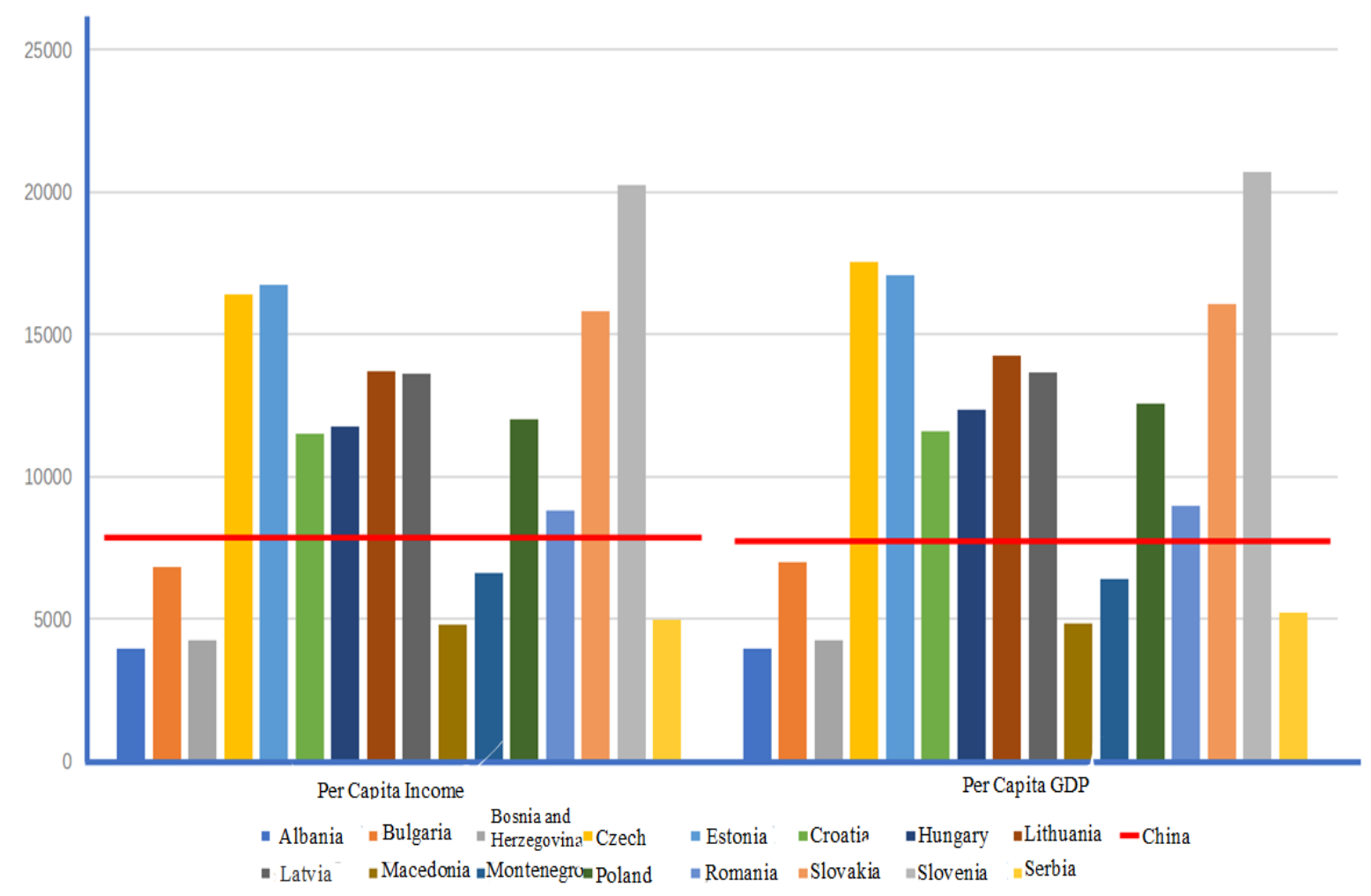

Figure 1 Per Capita Income and Per Capita GDP of China and 16 countries in CEE in 2015 (unit USD) Data Source: World Bank 


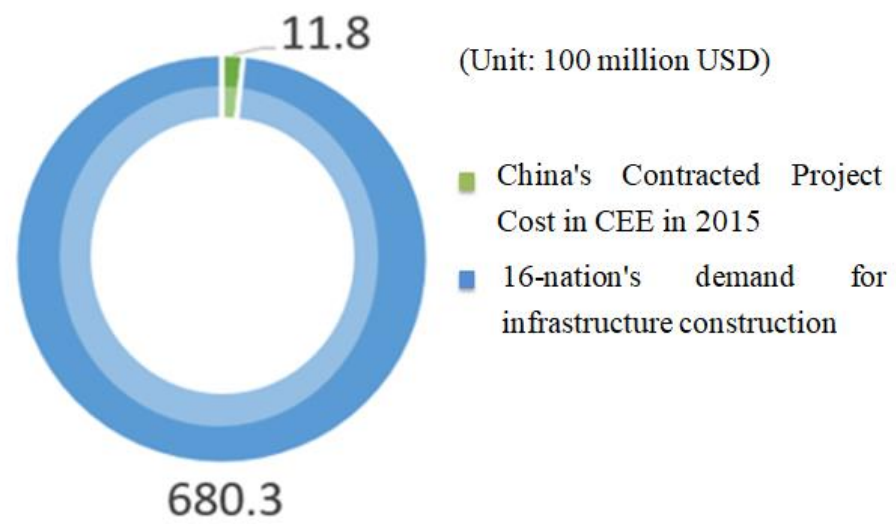

Figure 2 China's Contracted Projects in CEE

Data Sources: World Bank and Ministry of Commerce of the Peoples Republic of China

Table1 Serbia's railway construction planning project (2015)

\begin{tabular}{|l|l|l|}
\hline \multicolumn{1}{|c|}{ Name of capital construction } & $\begin{array}{c}\text { Amount } \\
\text { of money }\end{array}$ & \multicolumn{1}{|c|}{ Project description } \\
\hline $\begin{array}{l}\text { XI corridor, E - 763 highway, Bel- } \\
\text { grade - south of the Adriatic Sea: } \\
\text { Surčin - Obrenovac, and Preljina - } \\
\text { Boljare }\end{array}$ & $\begin{array}{l}495 \text { million } \\
\text { EUR }\end{array}$ & $\begin{array}{l}\text { Surčin-Obrenovac: 17.6 kilometers } \\
\text { Preljina-Požega: 30.96 kilometers } \\
\text { Obrenovac-Preljina: 103.14 kilometers }\end{array}$ \\
\hline $\begin{array}{l}\text { The part of XI corridor, E - 763 high- } \\
\text { way, Belgrade - south of the Adriatic } \\
\text { Sea: Preljina - Boljare. }\end{array}$ & $\begin{array}{l}1.8309 \text { bil- } \\
\text { lion EUR }\end{array}$ & Total length is 107 kilometers \\
\hline $\begin{array}{l}\text { The construction of Niš - Merdare } \\
\text { (-Priština) highway. }\end{array}$ & $\begin{array}{l}855 \text { million } \\
\text { EUR }\end{array}$ & $\begin{array}{l}\text { Construction Route: Niš-Prokuplje Merošina- } \\
\text { Pločnik-Kuršumlija-Merdare, the construction } \\
\text { section can achieve the highest internal rate of } \\
\text { return, there are totally 22 kilometers from } \\
\text { Merdare to Priština. }\end{array}$ \\
\hline $\begin{array}{l}\text { The modernized reform of Belgrade } \\
\text { of Serbia area-Budapest Railway } \\
\text { (The Railway Project of Hungary- } \\
\text { Serbia) }\end{array}$ & $\begin{array}{l}1.132 \text { bil- } \\
\text { lion EUR }\end{array}$ & $\begin{array}{l}\text { Reconstruction/Modernized reform Belgrade- } \\
\text { Budapest double line railway, speed 200 kilo- } \\
\text { meters per hour }\end{array}$ \\
\hline $\begin{array}{l}\text { The modernized reform of the rail- } \\
\text { way line between Serbia and Alba- } \\
\text { nia (area within the territory of Ser- } \\
\text { bia) }\end{array}$ & $\begin{array}{l}400 \text { million } \\
\text { EUR }\end{array}$ & $\begin{array}{l}\text { Including the reconstruction and modernized } \\
\text { reform of Lapovo-Kraljevo-Lesak railway, and } \\
\text { Lesak-Prizren railway and the construction of } \\
\text { Prizren-Skadar railway. This railway has suita- } \\
\text { ble development technology and characteris- } \\
\text { tics. }\end{array}$ \\
\hline $\begin{array}{l}\text { The reconstruction of Požarevac - } \\
\text { Majdanpek railway }\end{array}$ & $\begin{array}{l}30 \text { million } \\
\text { EUR }\end{array}$ & $\begin{array}{l}\text { The total length of the railway is 254 kilome- } \\
\text { ters, the railway is rebuilt and installed on the } \\
\text { route of retaining existing traffic lines, to make } \\
\text { the speed up to 100km/h, the shaft is allowed } \\
\text { to load 22.5 tons, the load of 8.0t/m is shared } \\
\text { by the railway. } \\
\text { Suitable communication, signal, and safety } \\
\text { system are equipped to the railway. }\end{array}$ \\
\hline
\end{tabular}




\begin{tabular}{|l|l|l|}
\hline Name of capital construction & $\begin{array}{c}\text { Amount } \\
\text { of money }\end{array}$ & \multicolumn{1}{|c|}{ Project description } \\
\hline $\begin{array}{l}\text { The reconstruction and moderniza- } \\
\text { tion reform of Pančevo-Zrenjanin- } \\
\text { Banatsko Miloševo-Senta-Subotica } \\
\text { railway }\end{array}$ & $\begin{array}{l}96 \text { million } \\
\text { EUR }\end{array}$ & $\begin{array}{l}\text { The railway is rebuilt and installed on the route } \\
\text { of retaining existing traffic line, to make the } \\
\text { speed up to 100km/h, the shaft is allowed to } \\
\text { load } 22.5 \text { tons, the load of } 8.0 \text { t/m is shared by } \\
\text { the railway. } \\
\text { Suitable communication, signal, and safety } \\
\text { system are equipped to the railway. }\end{array}$ \\
\hline $\begin{array}{l}\text { The reconstruction of Petrovaradin- } \\
\text { Beočin railway }\end{array}$ & $\begin{array}{l}16 \text { million } \\
\text { EUR }\end{array}$ & $\begin{array}{l}\text { The railway is rebuilt and installed on the route } \\
\text { of retaining existing traffic line, to make the } \\
\text { speed up to 100 km/h, the shaft is allowed to } \\
\text { load 255KN, a load of } 80 \mathrm{KN} / \mathrm{m} \text { is shared by the } \\
\text { railway. } \\
\text { Suitable communication, signal, and safety } \\
\text { system are equipped to the railway. } \\
\text { Railway Electrification. }\end{array}$ \\
\hline $\begin{array}{l}\text { The construction (reconstruction) of } \\
\text { Segedin-Horgoš-Subotica-Cikerija- } \\
\text { Baja railway }\end{array}$ & $\begin{array}{l}15 \text { bUR } \\
\text { EUllion }\end{array}$ & $\begin{array}{l}\text { The part of the railway through Hungary is sub- } \\
\text { sidized by the European Union and Hungary. }\end{array}$ \\
\hline $\begin{array}{l}\text { The reconstruction of Novi Sad - } \\
\text { Odžaci-Bogojevo railway }\end{array}$ & $\begin{array}{l}19 \text { million } \\
\text { EUR }\end{array}$ & $\begin{array}{l}\text { The railway is rebuilt and installed on the route } \\
\text { of retaining existing traffic line, speed up to } \\
100 / \mathrm{h} \text {, installed type rail, the shaft is allowed to } \\
\text { load 22.5t, the load of } 8 \mathrm{t}-\mathrm{m} \text { is shared by the } \\
\text { railway. } \\
\text { Suitable communication, safety signal system, } \\
\text { and signal tower are equipped to the railway. }\end{array}$ \\
\hline
\end{tabular}

Take Serbia as an example, Serbia's railways have been in disrepair for a long time, the equipment has been severely deteriorated, and the standard-reaching rate of railway facilities is only 44\%. According to the General Planning for Transport Infrastructure Construction in Serbia 2010-2027, Serbia will invest 22.2 billion euros in the construction of expressways, railways, airports, and ports in the next 17 years. It can be seen that Serbia has a huge demand for transportation infrastructure construction. Judging from the railway construction planning project announced by Serbia (the year 2015) (Table 1), Serbia mainly focuses on the modernization reconstruction and equipment renewal of railways, but due to the small scale of Serbian domestic companies and the substandard level of technology, it is difficult to undertake the construction of large-scale projects. So, the most railway construction is contracted to foreign companies. Therefore, there are great development opportunities for Chinese enterprises to enter the market in CEE.

\section{ANALYSIS OF DEVELOPMENT STATUS OF NINGBO TRAFFIC EQUIPMENT MANUFACTURING INDUSTRY}

Ningbo's transportation equipment manufacturing industry includes enterprises represented by rail traffic equipment, bridge engineering mechanical equipment and high-end ship equipment manufacturing enterprises. After years of development, Ningbo has emerged a group of advantageous enterprises with strong technical force and strong 
production capacity and has achieved an international leading level in many fields. Take Zhejiang Zhongrui Heavy Industry Technology Co., Ltd and Ningbo CRRC New Energy Technology Co., Ltd. as examples (Table 2), both enterprises have strong research and development teams, supercapacitors and drilling rig preparation technologies with fully autonomous intellectual property rights and the overall technology power is in the international leading position. In addition, the companies' products have participated in a number of well-known projects at home and abroad, which have accumulated rich practical operation and management experience for the infrastructure construction towards the international market. For example, the Hangzhou Bay Sea Cross Bridge and Bangladesh PADMA Bridge that Zhejiang Zhongrui Heavy Industry Technology Co., Ltd participates in the construction.

Zhejiang Zhongrui currently has only one branch company in Indonesia and its products are mainly sold in Southeast Asia. Hope to take advantages of the "One Belt and One Road" opportunity to set up branch companies or offices in countries around Europe to accelerate the promotion strength of Zhongrui products. Ningbo CRRC is a core subsidiary of CRRC Zhuzhou Investment Holding Co., Ltd. and has sales networks in the United States and Central and Western Asia countries. Although it is also involved in CEEC, it is limited to Poland, Serbia, and Croatia and other four or five countries, not yet throughout CEE. It can be seen that although the company has strong production capacity, advanced product technology, and rich practical operation and management experience, it has not penetrated into the vast market of CEE. However, the proposal of the "One Belt and One Road" strategy has provided a broader space and development platform for Ningbo enterprises to "Go Global". Enterprises are all hoping to take advantage of this to create, penetrate and occupy the markets in CEE.

\section{Table 2 Introduction of Ningbo typical transportation equipment manufacturing enterprise}

\begin{tabular}{|c|c|c|c|c|c|}
\hline Enterprise & $\begin{array}{l}\text { Main prod- } \\
\text { ucts }\end{array}$ & $\begin{array}{c}\text { Scientific research } \\
\text { level }\end{array}$ & $\begin{array}{c}\text { Technological su- } \\
\text { periority }\end{array}$ & Application fields & $\begin{array}{l}\text { Existing coop- } \\
\text { eration pro- } \\
\text { jects }\end{array}$ \\
\hline $\begin{array}{l}\text { Zhejiang } \\
\text { Zhongrui } \\
\text { Heavy In- } \\
\text { dustry }\end{array}$ & $\begin{array}{l}\text { All-hydraulic } \\
\text { drill rig }\end{array}$ & $\begin{array}{l}\text { Long-term coop- } \\
\text { erative relations } \\
\text { have been estab- } \\
\text { lished with many } \\
\text { scientific re- } \\
\text { search institutes } \\
\text { and universities, } \\
\text { such as Central } \\
\text { South University } \\
\text { and Zhejiang } \\
\text { University, and it } \\
\text { has independent } \\
\text { intellectual prop- } \\
\text { erty rights, and } \\
\text { has applied for } \\
\text { and obtained } \\
\text { more than } 20 \text { pa- } \\
\text { tents authorized } \\
\text { by the State Intel- } \\
\text { lectual Property } \\
\text { Office. }\end{array}$ & $\begin{array}{l}\text { 1. High efficiency } \\
\text { and energy sav- } \\
\text { ing, reliable and } \\
\text { stable transmis- } \\
\text { sion perfor- } \\
\text { mance. } \\
\text { 2. Effective con- } \\
\text { trol of perpendic- } \\
\text { ularity and aper- } \\
\text { ture accuracy, } \\
\text { and wear reduc- } \\
\text { tion of drilling } \\
\text { tools. } \\
\text { 3. Easy opera- } \\
\text { tion, low mainte- } \\
\text { nance cost and } \\
\text { comfortable oper- } \\
\text { ating room envi- } \\
\text { ronment. }\end{array}$ & $\begin{array}{l}\text { Ocean wind } \\
\text { power con- } \\
\text { struction of the } \\
\text { large bridges at } \\
\text { home and } \\
\text { abroad, port, } \\
\text { etc., sewage } \\
\text { treatment wells } \\
\text { and other engi- } \\
\text { neering fields. }\end{array}$ & $\begin{array}{l}\text { Hangzhou } \\
\text { Bay Sea } \\
\text { Cross } \\
\text { Bridge, Hong } \\
\text { Kong-Zhuhai- } \\
\text { Macao } \\
\text { Bridge, Ma- } \\
\text { laysia Pe- } \\
\text { nang Bridge, } \\
\text { Mozambique } \\
\text { Maputo } \\
\text { Bridge, Bang- } \\
\text { ladesh } \\
\text { PADMA } \\
\text { bridge, Fujian } \\
\text { Pingtan Gulf } \\
\text { Wind Farm } \\
\text { and so on. }\end{array}$ \\
\hline
\end{tabular}




\begin{tabular}{|c|c|c|c|c|c|}
\hline Enterprise & $\begin{array}{l}\text { Main prod- } \\
\text { ucts }\end{array}$ & $\begin{array}{c}\text { Scientific research } \\
\text { level }\end{array}$ & $\begin{array}{c}\text { Technological su- } \\
\text { periority }\end{array}$ & Application fields & $\begin{array}{c}\text { Existing coop- } \\
\text { eration pro- } \\
\text { jects }\end{array}$ \\
\hline $\begin{array}{l}\text { Ningbo } \\
\text { CRRC New } \\
\text { Energy } \\
\text { Technology } \\
\text { CO., LTD }\end{array}$ & $\begin{array}{l}60000 \mathrm{~F} \text { bat- } \\
\text { tery capaci- } \\
\text { tive super- } \\
\text { capacitor }\end{array}$ & $\begin{array}{l}\text { It sets up the } \\
\text { CRRC Super Ca- } \\
\text { pacitor Research } \\
\text { Institute and } \\
\text { Zhejiang Post- } \\
\text { doctoral Work- } \\
\text { station, bears } \\
\text { more than } 30 \text { sci- } \\
\text { entific research } \\
\text { projects such as } \\
\text { the national "863 } \\
\text { Project", national } \\
\text { science and tech- } \\
\text { nology major pro- } \\
\text { jects of MIIT" } \\
\text { Strong Industrial } \\
\text { Base Project } \\
2016 ", \text { Ningbo in- } \\
\text { dustrialization } \\
\text { project and key } \\
\text { research topics, } \\
\text { CRRC inner pro- } \\
\text { jects and so on. }\end{array}$ & $\begin{array}{l}\text { The energy den- } \\
\text { sity is } 40 \mathrm{Wh} / \mathrm{kg} \text {, } \\
\text { and the charging } \\
\text { time is only 6 } \\
8 \mathrm{~min} \text {, which can } \\
\text { enable the bus } \\
\text { (electric bus) to } \\
\text { travel more than } \\
20 \text { kilometers in } \\
\text { full load with one } \\
\text { charge time and } \\
\text { save electronic } \\
\text { power more than } \\
\text { one third than } \\
\text { that of conven- } \\
\text { tional trolley- } \\
\text { buses. }\end{array}$ & $\begin{array}{l}\text { It is used in su- } \\
\text { per electric en- } \\
\text { ergy tramcars, } \\
\text { trolleybuses. }\end{array}$ & $\begin{array}{l}\text { Supercapaci- } \\
\text { tor energy } \\
\text { storage trams } \\
\text { such as } \\
\text { Guangzhou } \\
\text { Haizhu } \\
\text { Roundabout } \\
\text { Tram, Shen- } \\
\text { zhen Long- } \\
\text { hua Line, and } \\
\text { Jiangsu } \\
\text { Huaian Line, } \\
\text { etc. superca- } \\
\text { pacitor en- } \\
\text { ergy storage } \\
\text { trolleybus, oil } \\
\text { and electric } \\
\text { hybrid car of } \\
\text { Ningbo bus } \\
\text { line; Guang- } \\
\text { zhou metro } \\
\text { 1500 line } \\
\text { storage sys- } \\
\text { tem. }\end{array}$ \\
\hline $\begin{array}{l}\text { AOTU } \\
\text { Heavy In- } \\
\text { dustry, CO., } \\
\text { LTD }\end{array}$ & $\begin{array}{l}\text { ME (350t } 10 \\
\text { r350t) uni- } \\
\text { versal gan- } \\
\text { try crane }\end{array}$ & $\begin{array}{l}\text { It has been es- } \\
\text { tablished the } \\
\text { R\&D Center of } \\
\text { the Provincial } \\
\text { High-tech Enter- } \\
\text { prise of AOTU } \\
\text { Heavy Industry. } \\
\text { Using its own } \\
\text { technology to get } \\
\text { the research } \\
\text { achievements of } \\
\text { Energy Saving } \\
\text { Technology for } \\
\text { Design of New } \\
\text { Type Hoisting } \\
\text { Machinery Light- } \\
\text { weight, which is } \\
\text { included in the } \\
\text { catalog of Na- } \\
\text { tional Key Energy }\end{array}$ & $\begin{array}{l}\text { It adopts all-fre- } \\
\text { quency PLC con- } \\
\text { trol technology, } \\
\text { overload protec- } \\
\text { tion, fault alarm } \\
\text { display laser } \\
\text { ranging and other } \\
\text { domestic and for- } \\
\text { eign advanced } \\
\text { technology, it can } \\
\text { be sensitive to } \\
\text { the slight } \\
\text { changes in the } \\
\text { lifting process. }\end{array}$ & $\begin{array}{l}\text { Advanced man- } \\
\text { ufacturing, mili- } \\
\text { tary industry, } \\
\text { rail transit, aer- } \\
\text { ospace, nuclear } \\
\text { power, coal, } \\
\text { chemical, elec- } \\
\text { tric power, ship- } \\
\text { building and } \\
\text { metallurgy and } \\
\text { other matched } \\
\text { fields. }\end{array}$ & $\begin{array}{l}\text { Ningbo rail- } \\
\text { way transport } \\
\text { line 1, line 2, } \\
\text { Wuxi railway } \\
\text { transport line } \\
2 \text {, and coop- } \\
\text { eration with } \\
\text { Sri Lanka, } \\
\text { Venezuela, } \\
\text { Nigeria and } \\
\text { other coun- } \\
\text { tries. }\end{array}$ \\
\hline
\end{tabular}




\begin{tabular}{|c|c|c|c|c|c|}
\hline Enterprise & $\begin{array}{l}\text { Main prod- } \\
\text { ucts }\end{array}$ & $\begin{array}{c}\text { Scientific research } \\
\text { level }\end{array}$ & $\begin{array}{c}\text { Technological su- } \\
\text { periority }\end{array}$ & Application fields & $\begin{array}{l}\text { Existing coop- } \\
\text { eration pro- } \\
\text { jects }\end{array}$ \\
\hline & & $\begin{array}{l}\text { Conservation } \\
\text { Technology Pro- } \\
\text { motion (fifth). } \\
\text { Two of new prod- } \\
\text { ucts obtain the } \\
\text { MOST Innovation } \\
\text { Fund, among } \\
\text { which } 1 \text { item is } \\
\text { listed in the } 2011 \\
\text { annual fund key } \\
\text { support project. }\end{array}$ & & & \\
\hline $\begin{array}{l}\text { Ningbo } \\
\text { Shangong } \\
\text { Intelligent } \\
\text { Security } \\
\text { Technology, } \\
\text { CO., LTD }\end{array}$ & $\begin{array}{l}\text { GFRP se- } \\
\text { ries fiber } \\
\text { grating } \\
\text { strain sen- } \\
\text { sor }\end{array}$ & $\begin{array}{l}\text { Now it has a full } \\
\text { set of equipment } \\
\text { and laboratory of } \\
\text { related technol- } \\
\text { ogy and auxiliary } \\
\text { product re- } \\
\text { search, R\&D } \\
\text { center respec- } \\
\text { tively In Hang- } \\
\text { zhou Binjiang } \\
\text { District, Ningbo } \\
\text { Wangchun In- } \\
\text { dustrial Park, } \\
\text { Harbin, bears the } \\
\text { national "863 } \\
\text { Project", the Na- } \\
\text { tional Science } \\
\text { and Technology } \\
\text { Support Plan and } \\
\text { so on scientific } \\
\text { research pro- } \\
\text { jects, as well as } \\
\text { also sets up Ex- } \\
\text { pert Committee } \\
\text { in which the } \\
\text { academician of } \\
\text { the Chinese Aca- } \\
\text { demic of Engi- } \\
\text { neering, the ex- } \\
\text { pert in The Re- } \\
\text { cruitment Pro- } \\
\text { gram of Global } \\
\text { Experts, Chang }\end{array}$ & $\begin{array}{l}\text { The engineering } \\
\text { test requires that } \\
\text { the standard dis- } \\
\text { tance of the ad- } \\
\text { justment range } \\
\text { can be up to } \\
1 \sim 2 \mathrm{~cm} \text {, which } \\
\text { has the ad- } \\
\text { vantages of sim- } \\
\text { ple project layout } \\
\text { and large range, } \\
\text { good durability, } \\
\text { and high preci- } \\
\text { sion, etc. }\end{array}$ & $\begin{array}{l}\text { Transportation } \\
\text { infrastructure, } \\
\text { urban public in- } \\
\text { frastructure, } \\
\text { civil engineer- } \\
\text { ing construc- } \\
\text { tion. }\end{array}$ & $\begin{array}{l}\text { Qinlai Ex- } \\
\text { pressway, } \\
\text { Wuhan Rail- } \\
\text { way Line4 the } \\
\text { Second } \\
\text { Phase Pro- } \\
\text { ject, Daqin } \\
\text { Railway } \\
\text { Bridge, } \\
\text { Jiangxi } \\
\text { Jiujiang } \\
\text { Bridge, etc. }\end{array}$ \\
\hline
\end{tabular}




\begin{tabular}{|l|l|l|l|l|l|}
\hline Enterprise & $\begin{array}{c}\text { Main prod- } \\
\text { ucts }\end{array}$ & $\begin{array}{c}\text { Scientific research } \\
\text { level }\end{array}$ & $\begin{array}{c}\text { Technological su- } \\
\text { periority }\end{array}$ & $\begin{array}{c}\text { Application fields } \\
\text { Existing coop- } \\
\text { eration pro- } \\
\text { jects }\end{array}$ \\
\hline & $\begin{array}{l}\text { Jiang Scholars, } \\
\text { and many other } \\
\text { well-known ex- } \\
\text { perts take the ex- } \\
\text { perts position. }\end{array}$ & & \\
\hline
\end{tabular}

\section{PROBLEMS IN THE "GO GLOBALLY" OF NINGBO'S TRANSPORT EQUIPMENT MANUFACTURING INDUSTRY}

\subsection{Face a variety of risks}

The "Go Globally" of Ningbo's transport equipment manufacturing industry faces various risks, including political risk, economic risk, social environmental risk, legal risk, contract risk, and cultural risk among different countries (Houming, 2015). Its concrete manifestations are shown in Table 3.
4.2 The "Go" of "Go Globally" is too blind In recent years, with the promotion of national policies, some enterprises in Ningbo have also gradually marched towards CEE. However, because most enterprises only use "Go Globally" as a short-term action to transfer old equipment, obtain investment subsidies, or enjoy preferential policies, they can't stand at the strategic height of corporate sustainable development to plan the "Go Globally" behavior of enterprises, thus limiting the international competitiveness of Ningbo's transport equipment manufacturing industry. At present, the "Go Globally" enterprises in Ningbo are too accustomed to fighting alone, and there is a lack of necessary cooperation among enterprises, and integrated innovation is rarer (Qin, 2017)

Table 3 Types of Risks that "Go Globally" of Ningbo's Transport Equipment Manufacturing Industry May Encounter

\begin{tabular}{|c|c|c|}
\hline Type & Specific Risk & Concrete Manifestation \\
\hline \multirow{3}{*}{$\begin{array}{l}\text { Uncontrolla- } \\
\text { ble Risk }\end{array}$} & Political risk & Political party replacement, terrorism, war \\
\hline & Economic risk & National sovereign credit risk, exchange rate risk \\
\hline & Environmental risk & $\begin{array}{l}\text { Destroy the natural environment, the opposition } \\
\text { of residents of the host country }\end{array}$ \\
\hline \multirow{3}{*}{$\begin{array}{l}\text { Controllable } \\
\text { Risk }\end{array}$} & Legal risk & Different legal systems \\
\hline & Contract risk & Irregular contract signing \\
\hline & $\begin{array}{l}\text { Cultural risks among different } \\
\text { countries }\end{array}$ & $\begin{array}{l}\text { The social system, cultural customs, religious } \\
\text { beliefs }\end{array}$ \\
\hline
\end{tabular}

\subsection{The "Go Globally" approach is rela- tively single}

The "Go Globally" strategy is divided into two levels: first, the output level of goods, including the output of goods and elements such as goods, services, technology, and management; and second, the output of capital, which is through foreign direct investment to build overseas factories (Guimin \& Ping., 2016(4): ). From the current situation in Ningbo City, Ningbo's transport equipment 
manufacturing industry still basically stays at the initial stage of the "Go Globally" strategy, that is, product output is the main factor, and technical output, service output, management output, and capital output are seriously insufficient.

\section{PATH STUDY OF TECHNOLOGY} ALLIANCE'S SERVICE FOR THE "GO GLOBALLY" OF NINGBO'S TRANSPORT EQUIPMENT MANUFACTURING INDUSTRY

\subsection{Conduct long-term forum activities to promote technical exchanges and industrial cooperation negotiations}

Since Ningbo became the first batch of innovative Table 4 Table of China-CEEC' Exchange Platforms

\begin{tabular}{|l|}
\hline $\begin{array}{l}\text { China-CEEC Forum on Cooperation Develop- } \\
\text { ment }\end{array}$ \\
\hline $\begin{array}{l}\text { China-CEEC Cooperation Conference for Cham- } \\
\text { ber of Commerce }\end{array}$ \\
\hline China-CEEC Educational Cooperation Forum \\
\hline $\begin{array}{l}\text { China-CEEC Educational Cooperation Confer- } \\
\text { ence }\end{array}$ \\
\hline $\begin{array}{l}\text { China-CEEC Tourism Cooperation and Exchange } \\
\text { Conference }\end{array}$ \\
\hline $\begin{array}{l}\text { China-CEEC Cooperation Seminar for Chamber } \\
\text { of Commerce }\end{array}$
\end{tabular}

\section{China-CEEC Investment Cooperation Meeting}

Fruit and Vegetable Meat Show of CEEC

The Overseas Chinese Businessman of CEEC Summit Ningbo China-CEEC Mayors Summit

At the exchange meeting, bilateral exchanges and consultations were held on the hot technical issues in the field of capital construction, and they conducted further communication and understanding of Zhejiang Zhongrui Heavy Industry Technology Co., Ltd.'s main product, hydraulic reverse circulation drilling rig. Afterward, the Serbian representative provided suggestions and related pilot cities in China in 2010, it has successively become China's first pilot demonstration city of "Made in China 2025" and one of the first two national demonstration parks for the transfer of scientific and technological achievements. The bi-directional exchange platform of China and CEEC has consecutively undertaken more than 20 activities since 2014 such as the CEEC Investment and Trade Expo and China-CEEC Investment Cooperation Meeting (Table 4).

Take the China-CEE Cooperation Forum held from June 9 to 12, 2017 as an example (Figure 3), during the forum, we visited Zhejiang Zhongrui Heavy Industry Technology Co., Ltd. with representatives from Bulgaria, Poland, the Czech Republic and Serbia and other countries.

\section{(Using Ningbo as the Host City)}

China-CEEC Commercial Chambers Investment and Business Symposium

Partnership for Connectivity China-CEEC Customs Cooperation Forum

China-CEEC Trade (Cross-Border E-Commerce) Symposium

China-CEEC People-to-people and Culture Exchange Activities

China-CEEC Culture and Arts Communication Activities

China (Ningbo)-Central and Eastern European Countries S\&T Achievements Promotion Communication Activities

China (Ningbo) -CEEC Economic \& Culture Exchange Week

China (Ningbo) -CEEC Investment Cooperation Industrial Park Promotion

Central and Eastern European Countries Products Fair

Guest of Honor Activities

information for Zhejiang Zhongrui Heavy Industry Technology Co., Ltd. to enter the CEE markets through the mail and helped to get in touch with the Minister of Transport, Republic of Serbia.

Through the existing work model, our experts have inspected foreign related enterprises and determined research directions and research plans. After the achievements are produced, Chinese 
experts negotiate cooperation with foreign partners and rush abroad to carry out relevant verification experiments. It is expected to achieve performance optimization and meet national standards and reach cooperation agreements to achieve achievements transfer and transformation cooperation.

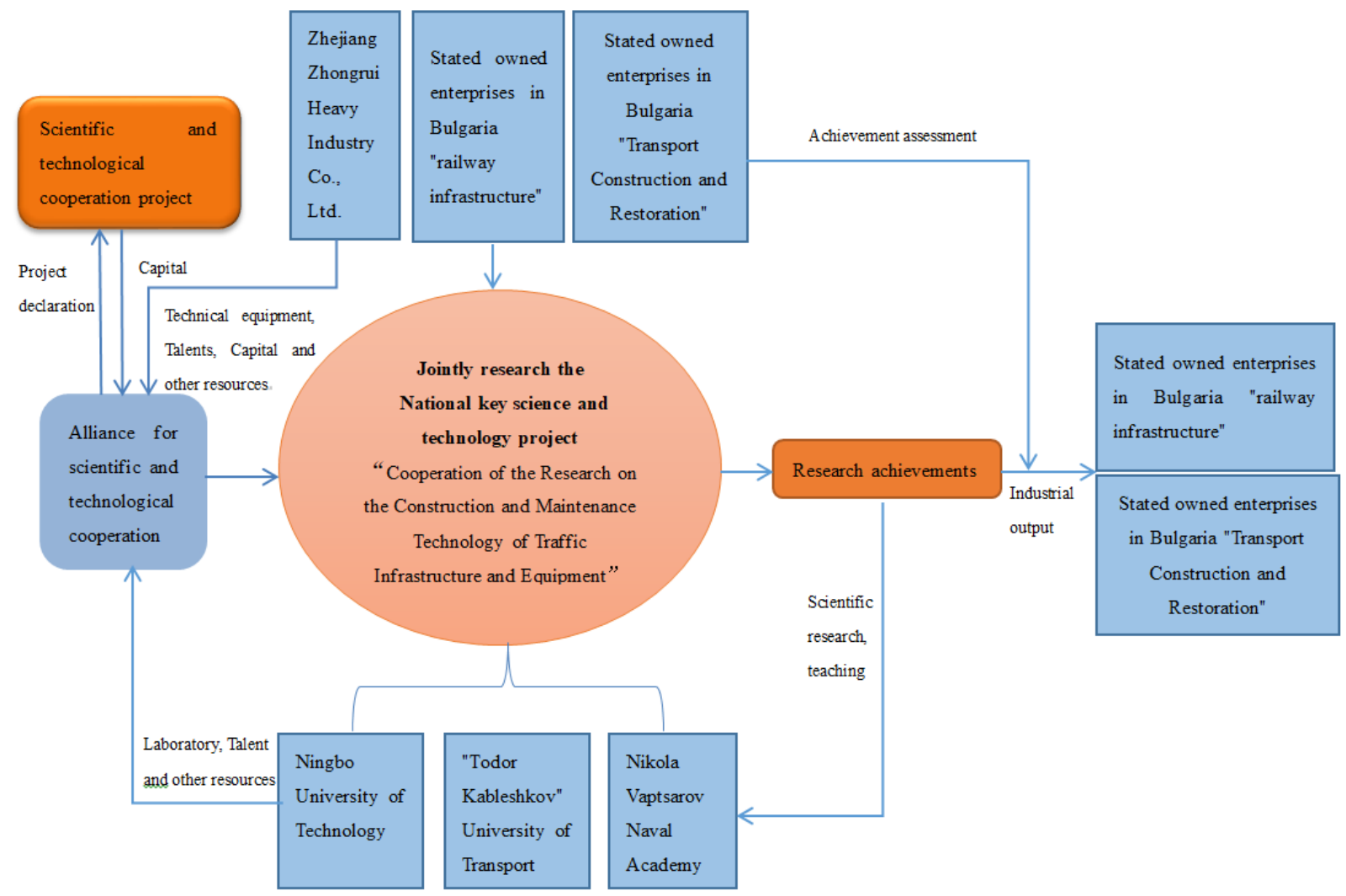

Figure 3 The flow chart of the conference activities

\subsection{Rely on International Scientific and Technological Cooperation Projects to Lead Capacity Output}

Since the implementation of the "One Belt and One Road" strategy, China has ushered in a good opportunity for international science and technology cooperation with CEEC. Over the years, our university and Bulgaria, Slovakia, and other Central and Eastern European countries have jointly declared more than 20 international science and technology cooperation projects represented by the National Key Science and Technology Program for "Cooperation in Research and Development of Harsh Environment Transport Infrastructure Construction and Maintenance Technology and Equipment", of which three items have been approved, and strived for 12 national talent projects. Through the joint application of scientific research projects, Ningbo and CEEC have achieved the output of leading production capacity relying on international science and technology cooperation projects (Figure 4).

The science and technology cooperation alliance has established a good cooperation relationship with more than 30 related scientific research institutions. On this basis, each person promotes the output of transport equipment technologies and standards by following up on their respective responsible enterprises, and the exchanges with relevant cooperative enterprises and colleges and universities in CEE. At the same time, the project's research achievements will be integrated. On the one hand, it will be negotiated with the principals of foreign colleges and universities to compile Ningbo's transport equipment and manufacturing technology into teaching materials, translate them into English or foreign official languages for colleges and universities' research and teaching; and on the other hand, it is used for the R\&D and transformation of existing equipment of enterprises to meet the special needs of the CEE markets, and 
to enter the 16-nation markets, and finally realize the output of products.

\subsection{Promote scientific research achievements and industrial dock- ing through deep integration of in- dustry-university-research}

alliance is a platform for promoting the transformation of scientific research achievements. It is a link and bridge for cooperation between scientific research institutes, universities, and enterprises. It can create opportunities for the docking of scientific research achievements and industry from the following two aspects:

The scientific and technological cooperation

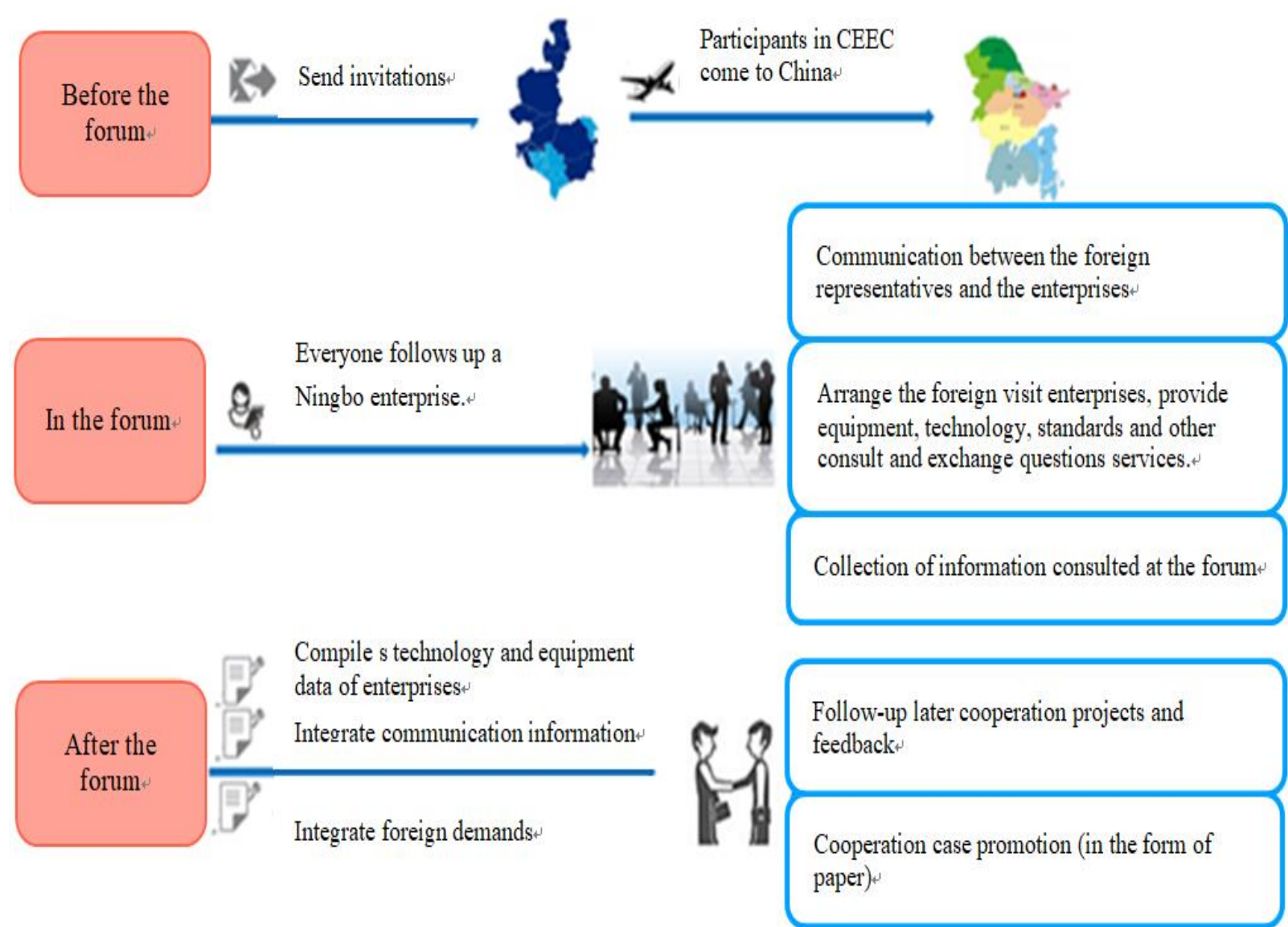

Figure 4 The pattern chart of science and technology cooperation project lead production output

1) Talent exchange and cooperation: Based on the cooperation basis of the scientific and technological cooperation alliance, assist Ningbo's enterprises, universities and research institutes to conduct training activities together in the field of transportation equipment manufacturing together with the universities and enterprises in CEEC (figure 5). Taking the talent cultivation as the goal, use 2-3 years to build a solid foundation and open a new prospect, and attract more than 50 scientific and technical personnel and engineers of different levels to Ningbo for training and exchange. Use about 8 years to break through the key points, advance the essence, and form a stable talent cultivation model for both sides.

2) Cooperation in decision-making consultation service: After Ningbo's enterprises have signed the contracts with enterprises in CEEC for the use of transportation equipment, and achieved the output of equipment and technology, by formulating a feedback system, the problems such as the running state of equipment, risen problems in the process of trial and use and others are fed back to the Ningbo's enterprises, then enterprise makes improvements to the equipment based on the 


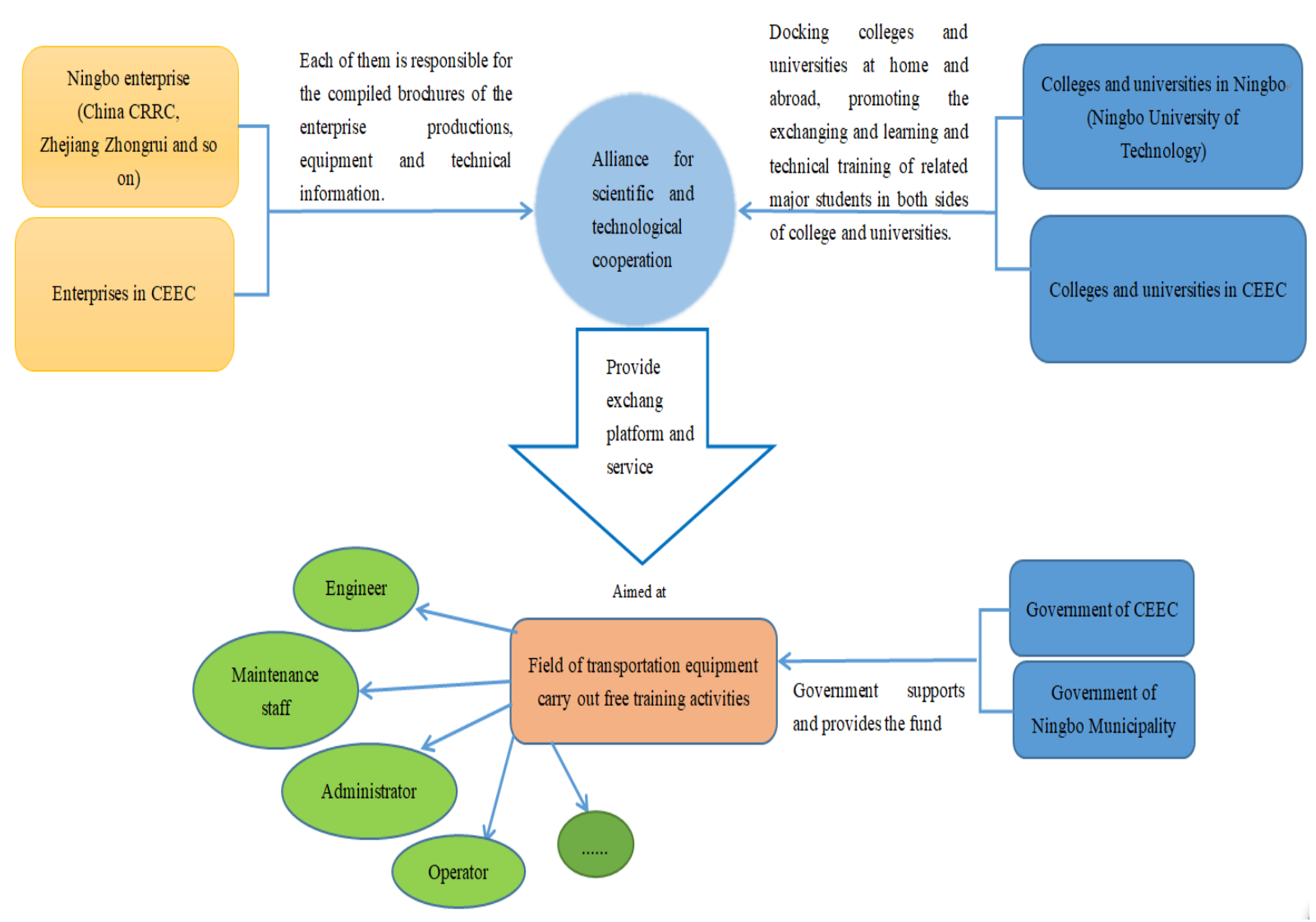

feedback.

Figure 5 Talent exchange training pattern chart

At the same time, combine with the various work in the early stage such as the development of conference activities, application of projects and output of enterprise technology equipment, etc. to master the external output requirements of enterprise technology and equipment as well as the special needs of the 16 countries in CEE, and to establish the direct subordination consulting team of Ningbo Municipal Human Resources and Social Security Bureau. And combined with the existing information to provide consulting services for more cooperation requirements for Ningbo and the 16 countries in CEE for the transportation equipment manufacturing industry.

\section{WORKS CITED}

Guimin, W., \& Ping., W. (2016(4): ). Status and Analysis of "Go Globally" in Liaoning Equipment Manufacturing Industry. Journal of Shenyang Normal University, 61-64.

Houming, Z. (2015). Research on "Go Globally" of China's Equipment Manufacturing Industry under the "One Belt and One Road" Strategy. Industrial Economy Review(9), 29-33.

Qin, D. (2017). Research on the "Go Globally" of Equipment Manufacturing in Liaoning under the New Situation. Journal of Shandong Institute of Business and Technology(6), 60-67.

Received for publication:

Revision Received:

Accepted for publication:
10.04.2018.

10.07.2018.

05.09.2018. 
How to cite this article?

Style - APA Sixth Edition:

Wang, B., \& Hu, D. (2018, 10 15). Research on the Development Path of Ningbo Transportation Equipment Manufacturing Industry in 16 CEEC. (Z. Čekerevac, Ed.) FBIM Transactions, 6(2), 195-207. doi:10.12709/fbim.06.06.02.20

Style - Chicago Sixteenth Edition:

Wang, Bo, and Danjuan Hu. 2018. "Research on the Development Path of Ningbo Transportation Equipment Manufacturing Industry in 16 CEEC." Edited by Zoran Čekerevac. FBIM Transactions (MESTE) 6 (2): 195-207. doi:10.12709/fbim.06.06.02.20.

Style - GOST Name Sort:

Wang Bo and Hu Danjuan Research on the Development Path of Ningbo Transportation Equipment Manufacturing Industry in 16 CEEC [Journal] // FBIM Transactions / ed. Čekerevac Zoran. - Beograd : MESTE, 10 15, 2018. - 2 : Vol. 6. - pp. 195-207.

Style - Harvard Anglia:

Wang, B. \& Hu, D., 2018. Research on the Development Path of Ningbo Transportation Equipment Manufacturing Industry in 16 CEEC. FBIM Transactions, 15 10, 6(2), pp. 195-207.

Style - ISO 690 Numerical Reference:

Research on the Development Path of Ningbo Transportation Equipment Manufacturing Industry in 16 CEEC. Wang, Bo and Hu, Danjuan. [ed.] Zoran Čekerevac. 2, Beograd : MESTE, 10 15, 2018, FBIM Transactions, Vol. 6, pp. 195-207.. 